\title{
Erratum to: Serum IgG against Candida predict survival in patients with metastatic renal cell carcinoma
}

\author{
Reinhold Ramoner • Andrea Rahm •
}

Claudia E. Falkensammer • Nicolai Leonhartsberger • Martin Thurnher

Published online: 13 May 2010

(C) Springer-Verlag 2010

Erratum to: Cancer Immunol Immunother

DOI 10.1007/s00262-010-0827-z

Unfortunately the original version has been published without the Conflict of interest statement. Please find below the statement.

Conflict of interest statement Martin Thurnher wishes to disclose that he has a financial interest in Sentimun Biotechnology and that he has filed a patent application that concerns the use of Candida IgG for cancer patient prognosis.

The online version of the original article can be found under doi:10.1007/s00262-010-0827-z.

R. Ramoner - A. Rahm - C. E. Falkensammer .

N. Leonhartsberger · M. Thurnher $(\bowtie)$

Immunotherapy Unit, Department of Urology,

Innsbruck Medical University, Innrain 66a,

6020 Innsbruck, Austria

e-mail: martin.thurnher@i-med.ac.at

Present Address:

R. Ramoner

Fachhochschule Gesundheit (FHG), Innsbruck, Austria 